\title{
New calcareous dinoflagellates from the Palaeogene of the South Atlantic Ocean (DSDP Site 357, Rio Grande Rise)
}

\author{
TANIA HILDEBRAND-HABEL \& HELMUT WILLEMS \\ Universität Bremen, Fachbereich Geowissenschaften, Postfach 330440, D-28334 Bremen, Germany.
}

\begin{abstract}
The new calcareous dinoflagellate taxa Bitorus truncus n.sp., Calcigonellum ansatum n.sp. and Fuettererella fungiforma n.sp. are formally described on the basis of Eocene and Oligocene samples from DSDP Site 357 (western South Atlantic Ocean). J. Micropalaeontol. 18(1): 89-95, June 1999.
\end{abstract}

\section{INTRODUCTION}

Calcareous dinoflagellates occur in significant quantities in many Mesozoic and Cenozoic marine sediments. However, for two main reasons the organisms have generally been overlooked in the past. As a result of their average size of $20-25 \mu \mathrm{m}$, they appear to be too small for foraminiferal studies and too large to be included in nannoplankton studies. Furthermore, they are dissolved during the preparation process for studies on organicwalled dinoflagellates.

Most information on fossil calcareous dinoflagellates focuses on Cretaceous material; few data on Palaeogene representatives are available. As a result of the interest in the Cretaceous/ Tertiary $(\mathrm{K} / \mathrm{T})$ boundary, the majority of studies on Palaeogene calcareous dinoflagellates deal with Palaeocene taxa exclusively (e.g. Fütterer, 1990; Kienel, 1994; Willems, 1996). Eocene and Oligocene forms have been subject to only a few studies (e.g. Weiler, 1990; Kohring, 1993; Keupp \& Kohring, 1994), and Fütterer $(1977,1984)$ alone has examined more extended time intervals, covering the entire Cenozoic.

This study concentrates on the description of new taxa in the Palaeogene of DSDP Site 357. It forms part of an extensive evaluation of the latest Cretaceous to early Neogene calcareous

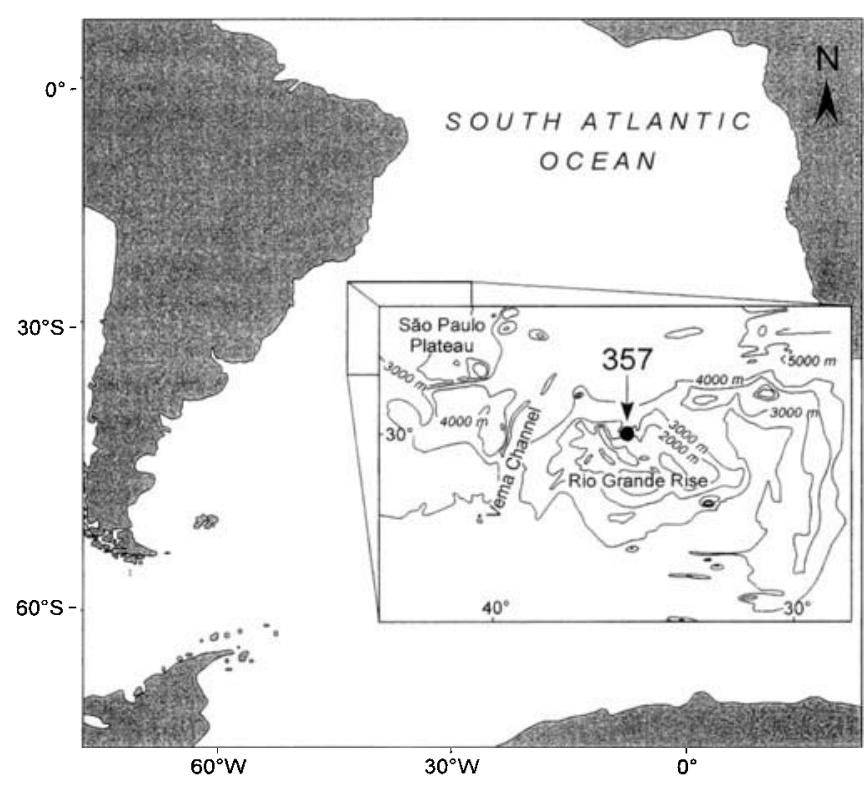

Fig. 1. Geographical location of DSDP Site 357 on the Rio Grande Rise. Bathymetry according to Shipboard Scientific Party (1977). dinoflagellate associations within two mid-latitude DSDP cores of the South Atlantic Ocean: Sites 356 and 357 (HildebrandHabel et al., in press; Hildebrand-Habel \& Willems, in press). The investigations focus particularly on the Palaeogene. This interval is exceptionally interesting, as it not only includes the recovery following the $\mathrm{K} / \mathrm{T}$ boundary, but also represents an intermediate stage between the warm Cretaceous and the colder Late Tertiary climates. It is marked by a general decline in temperature and shows significant palaeoceanographic changes (Miller et al., 1987; Crowley \& North, 1991; Berger \& Wefer, 1996).

The associations of calcareous dinoflagellates and the morphology of the tests are influenced by external factors (e.g. nutrients, insolation, temperature, salinity), and the organisms thus represent sensitive tools for palaeoreconstructions (e.g. Zonneveld et al., in press). By describing the three new species, the present study gives additional information about the poorly known Palaeogene assemblages of the South Atlantic Ocean. The systematic inventory may provide the background for subsequent analyses of the palaeoenvironmental signal of individual calcareous dinoflagellate taxa, as shown in Zonneveld et al. (in press).

\section{MATERIAL}

The study is based on core material recovered during DSDP Leg 39 (Shipboard Scientific Party, 1977) at Site $357\left(30^{\circ} 00.25^{\prime} \mathrm{S}\right.$, $35^{\circ} 33.59^{\prime} \mathrm{W}$ ) in the western South Atlantic Ocean (Fig. 1). The site was drilled in a water depth of $2086 \mathrm{~m}$ on the northern flank of the Rio Grande Rise. The cored section of $796.5 \mathrm{~m}$ mainly consists of pelagic, biogenic carbonates. Terrigenous components occur only sporadically and in insignificant quantities; siliceous organisms are important only in the lower to middle Eocene interval.

Inferred hiatuses occur in the Campanian, at the $\mathrm{K} / \mathrm{T}$ boundary, the Palaeocene/Eocene boundary, the Eocene/Oligocene boundary, and in the middle Miocene and Plio-Pleistocene (Shipboard Scientific Party, 1977).

A complete evaluation of the early Maastrichtian to early Miocene calcareous dinoflagellate assemblages of Site 357 is currently in preparation (Hildebrand-Habel \& Willems, in press). The present study concentrates on the introduction of new species occurring in this time interval. Samples of Site 357 which contain new species are listed in Table 1.

\section{METHODS}

The samples were processed as described by Willems (1996). They were treated with saturated Glauber's salt solution 
Table 1. Samples of DSDP core 39-357 containing the described new species of calcareous dinoflagellates. Nannoplankton zonation according to Martini (1971).

\begin{tabular}{lll}
\hline Sample (depth, cm) & Stratigraphy & New species \\
\hline $16-2(75-76)$ & Late Oligocene (NP 25) & Fuettererella fungiforma \\
$20-2(79-80)$ & Late Eocene (NP19) & $\begin{array}{l}\text { Bitorus truncus } \\
\text { Calcigonellum ansatum }\end{array}$ \\
$21-3(88-89)$ & Middle Eocene (NP 16) & Fuettererella fungiforma \\
\hline
\end{tabular}

$\left(\mathrm{Na}_{2} \mathrm{SO}_{4} \cdot 10 \mathrm{H}_{2} \mathrm{O}\right)$ and repeatedly frozen and defrosted to disintegrate the material. Afterwards, the samples were washed through a $20 \mu \mathrm{m}$ sieve and the residual fraction dried at $70^{\circ} \mathrm{C}$. The specimens were then picked using a binocular microscope at a magnification of $\times 256$ and stuck on scanning electron microscopy (SEM) stubs covered with adhesive stickers. The stubs were coated with gold and the morphotypes examined using a CamScan-44-SEM. Subsequently, some specimens were broken with a scalpel to allow examination of the wall structure.

To investigate the crystallographic orientation of the wallforming crystallites, several specimens of Calcigonellum ansatum n.sp. and Fuettererella fungiforma n.sp. were additionally prepared as described by Janofske (1996). They were mounted on the gelatinous surface of a transparent piece of developed photographic film by wetting with water; they were then coated with gold and examined using the scanning electron microscope. The film strip was then embedded in low viscosity resin and cut into $3 \mu \mathrm{m}$ thin sections using a rotation microtome. After embedding in Canada balsam, these thin sections were examined using a Zeiss Axioplan light microscope. Only the examination in polarized light enabled the exact determination of the crystallographic orientation of the wall-forming calcite crystals.

The original material is stored in the Division of Historical Geology and Palaeontology of the University of Bremen.

\section{SYSTEMATIC PALAEONTOLOGY}

Remarks. The suprageneric classification of calcareous dinoflagellates follows Fensome et al. (1993). These workers proposed a single subfamily Calciodinelloideae for dinoflagellate taxa with peridiniacean tabulation and a calcareous layer. Fensome et al. (1993) considered wall structures to be of unproved value in identifying phylogenetic relationships. On the contrary, Keupp (1987) and Kohring (1993) established a systematic concept of four subfamilies of calcareous dinoflagellate cysts based on the crystallographic orientation of the wallforming calcite crystals. These subfamilies are directly related to wall types after Young et al. (1997). Recent studies (Janofske, 1996; Montresor et al., 1997) proved the crystallographic orientation of calcite crystals to be species-specific, thus characterizing phylogenetic groupings. As a systematic revision of calcareous dinoflagellates, discussing all relevant morphological features, is currently in preparation (Janofske, pers. comm.), we continue using the classification according to Fensome et al. (1993).

Division Dinoflagellata (Bütschli, 1885) Fensome et al., 1993 Subdivision Dinokaryota Fensome et al., 1993 Class Dinophyceae Pascher, 1914

\author{
Subclass Peridiniphycidae Fensome et al., 1993 \\ Order Peridiniales Haeckel, 1894 \\ Suborder Peridiniineae Autonym \\ Family Peridiniaceae Ehrenberg, 1831 \\ Subfamily Calciodinelloideae Fensome et al., 1993
}

Genus Bitorus Keupp, 1992

Original diagnosis (Keupp, 1992: 500) 'The bicarinate orthopithonelloid cysts have a single-layered calcareous wall. The two prominent circular bulges are equivalent to the precingular and postcingular plates. The apical, conelike operculum $(=$ archaeopyle of exhausted cysts) includes the apical paraplates $2^{\prime}-4^{\prime \prime}$.'

\section{Bitorus truncus n.sp. \\ (Plate 1, figs 1-7)}

Derivation of name. Truncus (Latin) $=$ torso. With reference to the shape of the cyst, which resembles a torso.

Diagnosis. A species of Bitorus with two cingulum-parallel arranged rings of intratabular lobes: seven precingular and five postcingular. Wide depressions reflect the cingulum and sulcus. The single-layered wall consists of crystallites with radially oriented long axes.

Holotype. Cyst 116/36, SEM micrographs 116/6/3-6, 116/7/1-6, 130/7/2-6, 131/1/1-5, 136/4/4-5, 136/5/1-5 (Plate 1, figs 2-6).

Type locality. Rio Grande Rise, western South Atlantic, DSDP Leg 39, Site 357.

Type stratum. Late Eocene zone NP19; sample 39-357-20-2, 79 $80 \mathrm{~cm}$.

Paratypes. Cyst 116/17, SEM micrographs 115/1/1-5, 115/2/1-5, 128/6/5-6, 128/7/1-5, 129/1/1-4, 136/1/3-5 (Plate 1, fig. 1); cyst 116/35, SEM micrographs 116/4/1-6, 116/5/1-6, 130/5/3-6, 130/ 6/1-6, 130/7/1,136/3/5,136/6/1-3 (Plate 1, fig. 7).

Repository. Collection of the Division of Historical Geology and Palaeontology, Department of Geosciences, Bremen University, Germany.

Description. Bicarinate calcareous dinoflagellates with an incomplete reflection of precingular and postcingular plate equivalents. The apical face is subcircular and possesses a subcircular archaeopyle (Plate 1, fig. 1), possibly formed by the release of the paraplates $2^{\prime}-4^{\prime}$. Seven intratabular lobes, arranged in a ring framing the apical face, reflect the precingular plates (Plate 1, figs 2-4). Paraplate $1^{\prime}$ is not reflected by a lobe, instead an intercalated depression transits to the sulcus. The intersection of the depressions of sulcus and cingulum results in a wide, ventral plane (Plate 1, fig. 3). A ring of five intratabular lobes represents the postcingular paraplates (Plate 1, fig. 5). The only slightly convex antapical face shows no plate equivalent. The lobes may be indistinct; however, the ventral lobes always remain prominent.

The single-layered wall is composed of slim crystallites (Plate 1, fig. 6). The long axes of the crystallites are radially oriented, although the orientations of the crystallographic $c$-axes remain unproved.

Dimensions. Holotype: length $44 \mu \mathrm{m}$, width $43 \mu \mathrm{m}$, archaeopyle $19.9 \mu \mathrm{m}$, thickness of wall $6.0 \mu \mathrm{m}$. Other specimens: length 35 $36 \mu \mathrm{m}$, width $35-37 \mu \mathrm{m}$, archaeopyle $15.5-16.5 \mu \mathrm{m}$, thickness of wall $5.5-5.9 \mu \mathrm{m}$. 


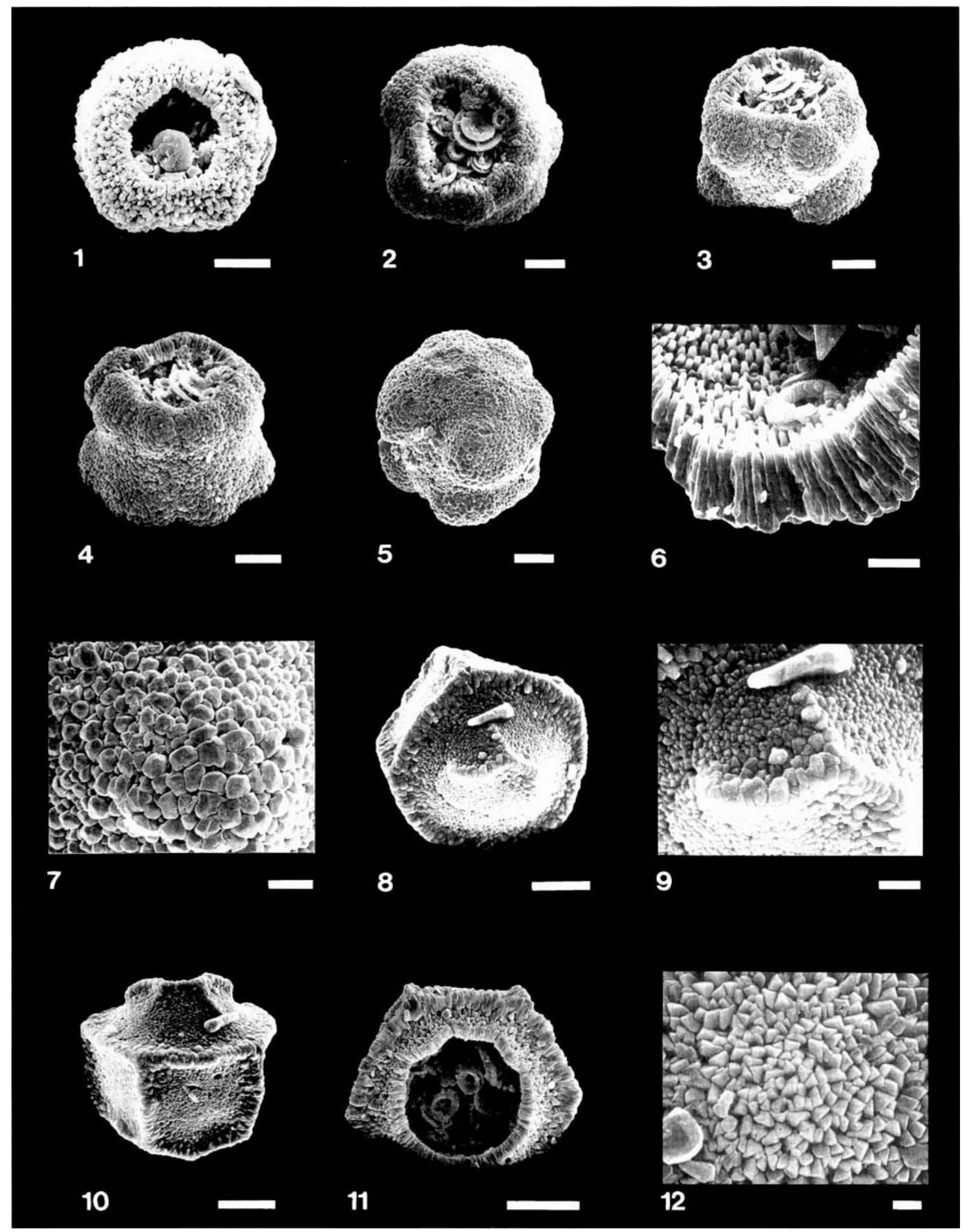

Explanation of Plate 1

New Palaeogene calcareous dinoflagellates from DSDP Site 357. figs 1-7. Bitorus truncus n.sp., core 39-357-20-2, 79-80 cm. fig. 1. Paratype, cyst 116 / 17, apical view. Scale bar $=10 \mu \mathrm{m}$. figs 2-6. Holotype, cyst $116 / 36$. fig. 2. Apical view. Scale bar $=10 \mu \mathrm{m}$. fig. 3. Ventral-apical view. Scale bar $=10 \mu \mathrm{m}$. fig. 4. Dorsal-apical view. Scale bar $=10 \mu \mathrm{m}$. fig. 5. Ventral-antapical view. Scale bar $=10 \mu \mathrm{m}$. fig. 6. Cross-section of wall. Scale bar $=3 \mu \mathrm{m}$. fig. 7. Paratype, cyst 116/35, distal surface. Scale bar $=3 \mu \mathrm{m}$. figs 8-12. Calcigonellum ansatum n.sp., core 39-357-20-2, 79-80 cm. figs 8-10. Holotype, cyst d/2. fig. 8. Apical view. Scale bar $=10 \mu \mathrm{m}$. fig. 9. Distal surface. Scale bar $=3 \mu \mathrm{m}$. fig. 10. Dorsal view. Scale bar $=10 \mu \mathrm{m}$. figs $11-12$. Paratype, cyst $116 / 23$. fig. 11. Apical view. Scale bar $=10 \mu \mathrm{m}$. fig. 12. Distal surface. Scale bar $=3 \mu \mathrm{m}$. 


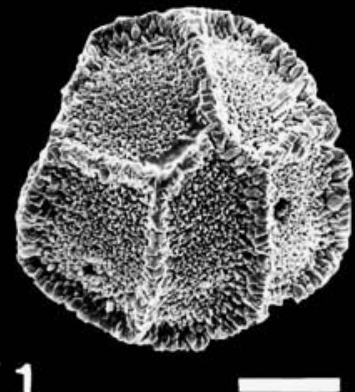

1

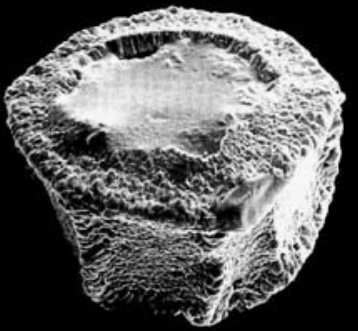

4

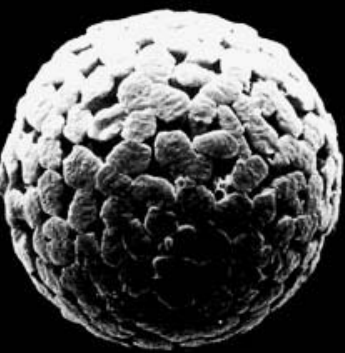

7

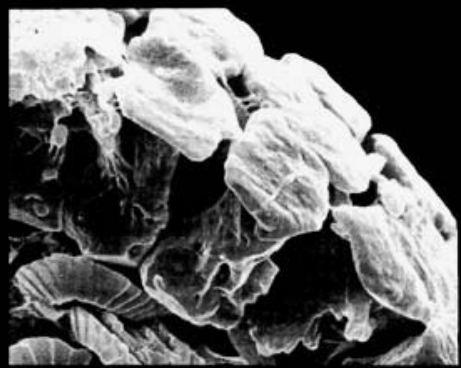

10

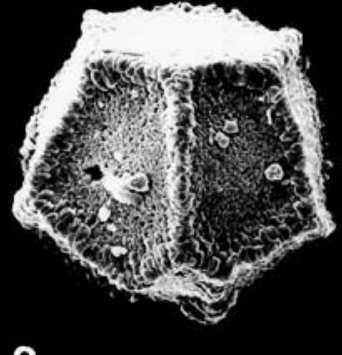

2

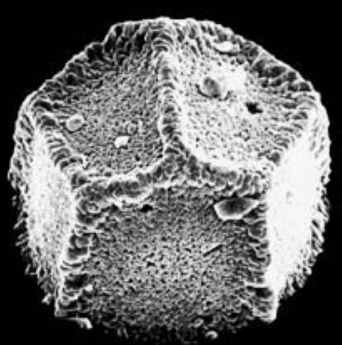

5

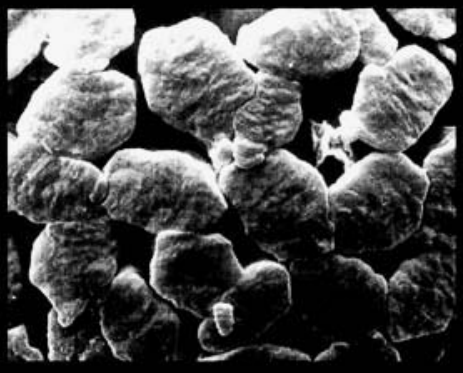

8

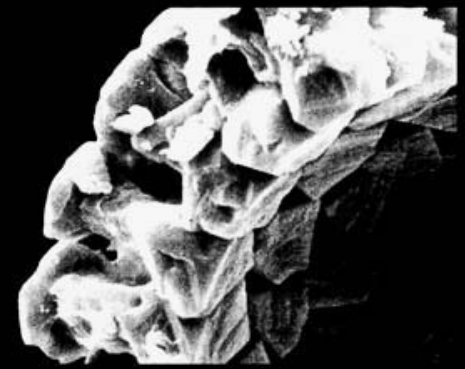

11

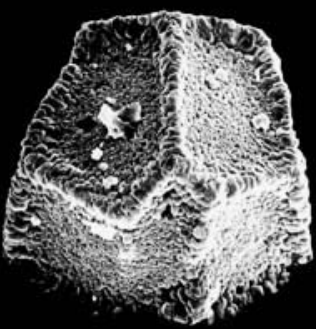

3

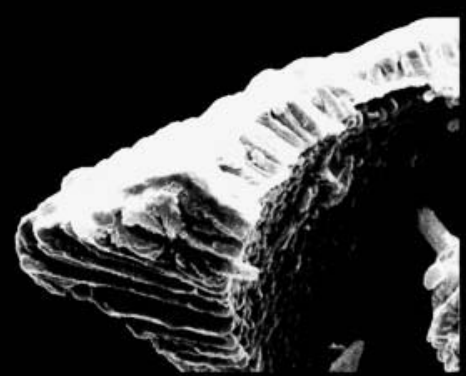

6

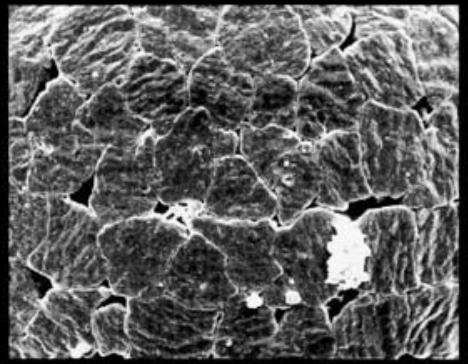

9

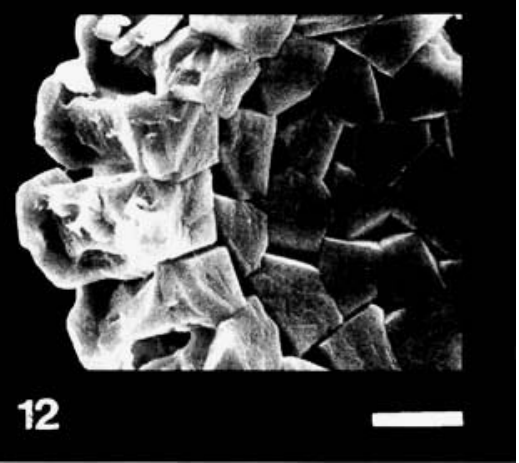

Explanation of Plate 2

New Palaeogene calcareous dinoflagellates from DSDP Site 357. figs 1-6. Calcigonellum ansatum n.sp., core 39-357-20-2, 79-80 cm. fig. 1. Paratype, cyst 116/33, antapical-ventral view. Scale bar $=10 \mu \mathrm{m}$. figs 2-6. Paratype, cyst 116/15. fig. 2. Antapical view. Scale bar $=10 \mu \mathrm{m}$. fig. 3. Antapicalventral view. Scale bar $=10 \mu \mathrm{m}$. fig. 4. Apical-ventral view. Scale bar $=10 \mu \mathrm{m}$. fig. 5. Antapical-dorsal view. Scale bar $=10 \mu \mathrm{m}$. fig. 6. Cross-section of wall. Scale bar $=3 \mu \mathrm{m}$. figs 7-12. Fuettererella fungiforma $\mathrm{n} . \mathrm{sp}$. figs 7-8. Holotype, cyst 113/76, core 39-357-21-3, 88-89 cm. fig. 7. Lateral view. Scale bar $=10 \mu \mathrm{m}$. fig. 8. Distal surface. Scale bar $=3 \mu \mathrm{m}$. fig. 9. Paratype, cyst $121 / 99$, core $39-357-16-2,75-76 \mathrm{~cm}$, distal surface. Scale bar $=3 \mu \mathrm{m}$. fig. 10. Paratype, cyst 114/14, core 39-357-21-3, 88-89 cm, cross-section of wall. Scale bar $=1 \mu \mathrm{m}$. figs 11-12. Paratype, cyst 113/38, core $39-357-21-3,88-$ $89 \mathrm{~cm}$. fig. 11. Cross-section of wall. Scale bar $=3 \mu \mathrm{m}$. fig. 12. Proximal surface. Scale bar $=3 \mu \mathrm{m}$. 
Comparison. Bitorus truncus differs from the two other species of Bitorus, B. turbiformis Keupp, 1992 and B. bulbjergensis Kienel, 1994 , in possessing intratabular lobes reflecting the precingular and postcingular paraplate equivalents.

Occurrence. Rare in the late Eocene of the Rio Grande Rise, sample $39-357-20-2,79-80 \mathrm{~cm}$.

Genus Calcigonellum Deflandre, 1948; emend. Keupp, 1984; emend. Keupp \& Versteegh, 1989

Emended diagnosis (translated from Keupp \& Versteegh, 1989: 211) 'Dinoflagellate cysts with a single-layered, radial-fibrous calcareous wall. The parasutural paratabulation is characterised by large, prismatic areas constructed by fused pre- and postcingular homologues. The large, apical archaeopyle at least integrates the homologues of the apical and intercalary plates.'

Calcigonellum ansatum $\mathrm{n} . \mathrm{sp}$.

(Plate 1, figs 8-12; Plate 2, figs 1-6; Fig. 2) a

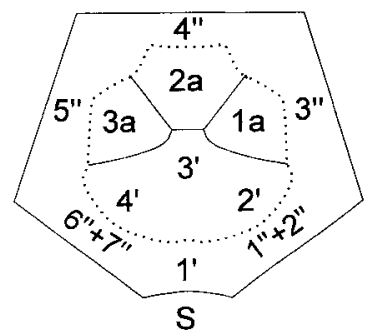

b

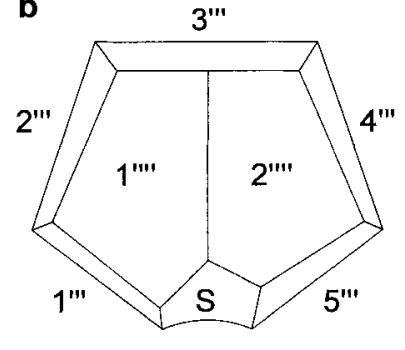

Fig. 2. Schematic diagram of the orthoperidinioid paratabulation of Calcigonellum ansatum n.sp. (a) Apical view; archaeopyle suture dotted. (b) Antapical view.

Derivation of name. Ansatus (Latin) = provided with handles. With reference to the handle-like structure of ridges on the operculum.

Diagnosis. A species of Calcigonellum with reduced paratabulation pattern in the roof-shaped epitract. The operculum features a handle-like structure of ridges. The antapex is slightly asymmetrical.

Holotype. Cyst d/2, SEM micrographs Ds/d/3/4-5, Ds/d/4/1-5, Ds/d/5/1-5, Ds/d/6/1-4 (Plate 1, figs 8-10).

Type locality. Rio Grande Rise, western South Atlantic, DSDP Leg 39, Site 357.

Type stratum. Late Eocene zone NP19; sample 39-357-20-2, 79 $80 \mathrm{~cm}$.

Paratypes. Cyst 116/23, SEM micrographs 114/6/4-5, 114/7/1-5, $115 / 3 / 1-5,115 / 4 / 1,129 / 5 / 6,129 / 6 / 1-6,129 / 7 / 1-2,136 / 2 / 2-5,136 /$ 2/1-2 (Plate 1, figs 11-12); cyst 116/33, SEM micrographs $115 / 7 /$ $6,116 / 1 / 1-4,116 / 2 / 1-3,116 / 3 / 1-4,130 / 2 / 2-5,103 / 3 / 1-4,130 / 4 / 1-$ 3, 136/2/3-4 (Plate 2, fig. 1); cyst 116/15, SEM micrographs $113 /$ $1 / 4-6,113 / 2 / 1-5,113 / 3 / 1-4,128 / 2 / 3-6,128 / 3 / 1-4,128 / 4 / 1-3,135 /$ 7/6, 136/1/1-2 (Plate 2, figs 2-6).

Repository. Collection of the Division of Historical Geology and Palaeontology, Department of Geosciences, Bremen University, Germany.

Description. The apical face of this holotabulate cyst has a pentagonal shape (Plate 1, fig. 8). Handle-like arranged ridges are situated on the operculum, separating the three intercalary plates 1a-3a from each other, and from the fused apical plates $2{ }^{\prime}-4^{\prime}$ (Plate 1, figs 8-10; Fig. 2). The ridges thus cause a roofshaped epicyst (Plate 1, fig. 10). Plates 1', and $1^{\prime \prime}-7^{\prime \prime}$ are not distinguished. The hypocyst shows five large, postcingular plates $1^{\prime \prime \prime}-5^{\prime \prime \prime}$ (Plate 2, figs 2-5). The sulcus is $9.2-10.7 \mu \mathrm{m}$ wide and always shows a homogeneous width in a single specimen (Plate 2 , figs 1, 3 and 4). The antapex exhibits two large $1^{\prime \prime \prime \prime}$ and $2^{\prime \prime \prime \prime}$ plates (Plate 2, figs 2, 3 and 5). Characteristically, the ridge separating sulcus and plate $1^{\prime \prime \prime \prime}$ is longer than the ridge separating sulcus and $2^{\prime \prime \prime \prime}$, inducing a slightly asymmetrical arrangement (Plate 2, figs 2 and 3). The average length/width ratio of the cysts is around 1.0 .

The single-layered wall consists of stemmed crystallites. Distal elongation of several rows of crystals constitutes the ridges (Plate 2, fig. 6). The crystallographic c-axes are tangentially oriented; however, the long axes are of radial orientation; this corresponds to the tangential wall type after Young et al. (1997). Dimensions. Holotype: length $33 \mu \mathrm{m}$, width $42 \mu \mathrm{m}$, archaeopyle $23.1 \mu \mathrm{m}$, minimal thickness of wall $1.7 \mu \mathrm{m}$, maximum thickness of wall $7.8 \mu \mathrm{m}$. Other specimens: length $24-35 \mu \mathrm{m}$, width $28-$ $34 \mu \mathrm{m}$, archaeopyle $17.5-22.5 \mu \mathrm{m}$, minimal thickness of wall 2.0 $2.5 \mu \mathrm{m}$, maximum thickness of wall $4.7-7.5 \mu \mathrm{m}$.

Comparison. The elongation of crystal-rows stresses the close affinity of Calcigonellum ansatum to the other two species of Calcigonellum, i.e. C. infula Deflandre, 1948 and C. granulata Kohring, 1993. The species show different expressions of the peridinoid paratabulation pattern, however. Additionally, the shape of the Calcigonellum species vary. The cysts of $C$. infula are notably elongated, whereas the cysts of $C$. granulata are almost spherical.

Occurrence. Rare in the late Eocene of the Rio Grande Rise, sample $39-357-20-2,79-80 \mathrm{~cm}$.

\section{Genus Fuettererella Kohring, 1993}

Original diagnosis. (Kohring, 1993: 88) 'Calcareous dinoflagellate cyst with a pseudoorthopithonelloid outer wall, however wall crystals with the c-axis parallel to the cysts surface.'

\section{Fuettererella fungiforma n.sp.}

(Plate 2, figs 7-12)

Derivation of name. Fungus (Latin) = mushroom; forma (Latin) $=$ form. With reference to mushroom-shaped crystals.

Diagnosis. Atabulate, strictly spherical calcareous dinoflagellate cysts. The single-layered wall consists of mushroom-shaped crystals with tangentially oriented $c$-axes. Crystal-tops widen and flatten, forming a distal surface of thin, undulated plates.

Holotype. Cyst 113/76, SEM micrographs 175/4/5, 175/5/1-2, 204/3/4-5, 204/4/1 (Plate 2, figs 7-8).

Type locality. Rio Grande Rise, western South Atlantic, DSDP Leg 39, Site 357.

Type stratum. Middle Eocene zone NP16; sample 39-357-21-3, $88-89 \mathrm{~cm}$.

Paratypes. Cyst 121/99, SEM micrographs 208/7/3-5, 209/1/1-3 (Plate 2, fig. 9); cyst 114/4, SEM micrographs 176/6/2-4, 176/7/12, 204/5/3-5, (Plate 2, fig. 10); cyst 113/38, SEM micrographs 
$173 / 3 / 5,173 / 4 / 1-3,210 / 6 / 5,210 / 7 / 1-5,211 / 1 / 1$, (Plate 2, figs 11 and 12 ).

Repository. Collection of the Division of Historical Geology and Palaeontology, Department of Geosciences, Bremen University, Germany.

Description. The spherical cysts show no paratabulation pattern (Plate 2, fig. 7). The thick calcareous wall is single-layered and consists of mushroom-shaped crystals (Plate 2, figs 10 and 11). Under the light microscope in crossed nicols and with gypsum plate, thin sections exhibit clear interference colours and have a positive optic sign. The species is thus assigned to the tangential wall type after Young et al. (1997). Each individual crystal is proximally based on a solid, polygonal plate with distinct edges (Plate 2, figs 11 and 12). The crystals taper distally and continue as relatively slim stems until they widen again and constitute flat, distal plates (Plate 2, fig. 10). These undulated plates may be oval-shaped (Plate 2, figs 7 and 8 ) or polygonal, and commonly fuse, producing a homogenous surface (Plate 2, fig. 9). In the studied material, no archaeopyle has been observed.

Dimensions. Holotype: length $36.5 \mu \mathrm{m}$, width $36.5 \mu \mathrm{m}$, thickness of wall $5.2 \mu \mathrm{m}$. Other specimens: length $31.5-43.5 \mu \mathrm{m}$, width 31.6-43.5 $\mu \mathrm{m}$, thickness of wall $4.9-5.7 \mu \mathrm{m}$.

Comparison. Common to all species of Fuettererella is the tangential orientation of the crystallographic $c$-axes; however, the orientation of the morphological long axes is perpendicular to the cysts' surface. $F$. fungiforma differs from the other species of Fuettererella, i.e. F. conforma Kohring, 1993, F. tesserula (Fütterer, 1977) Kohring, 1993, and F. elliptica Kohring, 1993, in the unique shape of the crystals, which do not show distinct crystal faces.

Occurrence. Common in the middle Eocene NP19 and rare in the late Oligocene NP25 of the Rio Grande Rise (samples 39$357-21-3,88-89 \mathrm{~cm}$, and $39-357-16-2,75-76 \mathrm{~cm})$.

\section{SUMMARY}

From the Eocene and Oligocene of DSDP Site 357, three new species of calcareous dinoflagellates are described. We thereby add information to the poorly known Palaeogene calcareous dinoflagellate assemblages of the western South Atlantic Ocean. By using both scanning electron and polarized light microscopy, tangential wall types have been proved for Calcigonellum ansatum n.sp. and Fuettererella fungiforma n.sp. The crystallographic orientations of the $c$-axes within Bitorus truncus, however, remain unverified.

\section{ACKNOWLEDGEMENTS}

The investigation was financially supported by the German Science Foundation (Deutsche Forschungsgemeinschaft, Wi $725 / 10$ ). The studied material was provided by the Deep Sea Drilling Project/Ocean Drilling Program. We are particularly grateful to the reviewers for their constructive reviews. Furthermore, we thank Mahyar Mohtadi for the preparation of thin sections, and Andreas Habel for assistance not only in the photo laboratory.

\section{Manuscript received 9 November 1998 Manuscript accepted March 1999}

\section{REFERENCES}

Berger, W. H. \& Wefer, G. 1996. Expeditions into the past: paleoceanographic studies in the South Atlantic. In Wefer, G., Berger, W. H., Siedler, G. \& Webb, D. J. (Eds), The South Atlantic: Present and Past Circulation. Springer, Berlin, Heidelberg, New York: 363410.

Bütschli, O. 1885. Protozoa. In Bronn, H. G. (Ed.), Klassen und Ordnungen des Thier-Reichs, wissenschaftlich dargestellt in Wort und Bild. Vol. 1. Wintersche Verlagsbuchhandlung, Leipzig: 865-1088.

Crowley, T. J. \& North, G. R. 1991. Paleoclimatology. Oxford Monographs on Geology and Geophysics, Oxford, 18: 339 pp.

Deflandre, G. 1948. Les Calciodinellidés. Dinoflagellés fossiles à thèque calcaire. Le Botaniste, Caen, 34: 191-219.

Ehrenberg, C. G. 1831. Animalia evertebrata. In Hemprich, P. C. \& Ehrenberg, C. G. (Eds), Symbolae Physicae. Pars Zoologica. Abhandlungen der deutschen Akademie der Wissenschaften, Berlin.

Fensome, R. A., Taylor, F. J. R., Norris, G., Sarjeant, W. A. S., Wharton, D. I. \& Williams, G. L. 1993. A classification of living and fossil dinoflagellates. Micropaleontology, Special Publication, 7: 351 pp.

Fütterer, D. K. 1977. Distribution of calcareous dinoflagellates in Cenozoic sediments of Site 366, eastern North Atlantic. In Lancelot, Y., Seibold, E. et al. (Eds), Initial Reports of the Deep Sea Drilling Project, 41: 709-737.

Fütterer, D. K. 1984. Pithonelloid calcareous dinoflagellates from the Upper Cretaceous and Cenozoic of the southeastern Atlantic Ocean, Deep Sea Drilling Project 74. In Moore, T. C., Rabinowitz, P. D. et al (Eds), Initial Reports of the Deep Sea Drilling Project, 74: 533-541.

Fütterer, D. K. 1990. Distribution of calcareous dinoflagellates at the Cretaceous-Tertiary boundary of Queen Maud Rise, eastern Weddell Sea, Antarctica (ODP Leg 113). In Barker, P. F., Kennett, J. P. et al. (Eds), Proceedings of the Ocean Drilling Program, Scientific Results, 113: $533-548$.

Haeckel, E. 1894. Systematische Phylogenie. Entwurf eines natürlichen Systems der Organismen auf Grund ihrer Stammesgeschichte. I. In Systematische Phylogenie der Protisten und Pflanzen. Reimer, Berlin: $400 \mathrm{pp}$.

Hildebrand-Habel, T. \& Willems, H. Distribution of calcareous dinoflagellates from the Maastrichtian to early Miocene of DSDP Site 357 (Rio Grande Rise, western South Atlantic Ocean). Geologische Rundschau, in press.

Hildebrand-Habel, T., Willems, H. \& Versteegh, G. J. M. Variations in calcareous dinoflagellate associations from the Maastrichtian to middle Eocene of the western South Atlantic Ocean (São Paulo Plateau, DSDP Leg 39, Site 356). Review of Palaeobotany and Palynology, in press.

Janofske, D. 1996. Ultrastructure types in Recent 'calcispheres'. Bulletin de l'Institut océanographique Monaco, 14(4): 295-427.

Keupp, H. 1984. Revision der kalkigen Dinoflagellaten-Zysten G. Deflandres, 1948. Paläontologische Zeitschrift, 58(1/2): 9-13.

Keupp, H. 1987. Die kalkigen Dinofiagellatenzysten des Mittelalb bis Untercenoman von Escalles/Boulonnais (N-Frankreich). Facies, 16: 37-88.

Keupp, H. 1992. Calcareous dinoflagellate cysts from the Lower Cretaceous of Hole 761C, Wombat Plateau, Eastern Indian Ocean. In von Rad, U., Haq, B. U. et al. (Eds), Proceedings of the Ocean Drilling Program, Scientific Results, 122: 497-509.

Keupp, H. \& Kohring, R. 1994. Kalkige Dinoflagellaten-Zysten aus dem Rupelton (Mittel-Oligozän) des Mainzer Beckens und der Niederrheinischen Bucht. Mainzer geowissenschaftliche Mitteilungen, 23: 159-184

Keupp, H. \& Versteegh, G. 1989. Ein neues systematisches Konzept für kalkige Dinoflagellaten-Zysten der Subfamilie Orthopithonelloideae Keupp 1987. Berliner Geowissenschaftliche Abhandlungen (A), 106: 207-219.

Kienel, U. 1994. Die Entwicklung der kalkigen Nannofossilien und der kalkigen Dinoflagellaten-Zysten an der Kreide/Tertiär-Grenze in Westbrandenburg im Vergleich mit Profilen in Nordjütland und Seeland (DK). Berliner geowissenschaftliche Abhandlungen (E), 12: 87 pp.

Kohring, R. 1993. Kalkdinoflagellaten aus dem Mittel- und Obereozän 
von Jütland (Dänemark) und dem Pariser Becken (Frankreich) im Vergleich mit anderen Tertiär-Vorkommen. Berliner geowissenschaftliche Abhandlungen (E), 6: $164 \mathrm{pp}$.

Martini, E. 1971. Standard Tertiary and Quaternary calcareous nannoplankton zonation. In Farinacci, A. (Ed.), Proceedings of the Second Planktonic Conference, Rome 1970. Tecnoscienzia, 739-785.

Miller, K. G., Janecek, T. R., Katz, M. E. \& Keil, D. J. 1987. Abyssal circulation and benthic foraminiferal changes near the Paleocene/ Eocene boundary. Paleoceanography, 2(6): 741-761.

Montresor, M., Janofske, D. \& Willems, H. 1997. The cyst-theca relationship in Calciodinellum operosum emend. (Peridiniales, Dinophyceae) and a new approach for the study of calcareous cysts. Journal of Phycology, 33: 122-131.

Pascher, A. 1914. Über Flagellaten und Algen. Berichte der deutschen Botanischen Gesellschaft Berlin, 32: 136-160.
Shipboard Scientific Party 1977. Volume 39. In Supko, P. R., PerchNielsen, K. et al. (Eds), Initial Reports of the Deep Sea Drilling Project, 39: 1139 pp.

Weiler, H. 1990. Calcisphaeren aus den oligozänen Schichten des Mainzer Beckens und des Oberrheingrabens. Mainzer geowissenschaftliche Mitteilungen, 19: 9-48.

Willems. H. 1996. Calcareous dinocysts from the Geulhemmerberg K/T boundary section (Limburg, SE Netherlands). Geologie en Mijnbouw, 75: $215-231$.

Young, J. R., Bergen, J. A., ef al. 1997. Guidelines for coccolith and calcareous nannofossil terminology. Palaeontology, 40: 875-912.

Zonneveld, K. A. F., Höll, C., Janofske, D., Karwath, B., Kerntopf, B., Rühlemann, C. \& Willems, H. Calcareous dinoflagellate cysts as palaeo-environmental tools. In Fischer, G. \& Wefer, G. (Eds), Use of Proxies in Paleoceanography: Examples from the South Atlantic. Springer, Berlin, Heidelberg, in press. 